\title{
Impact of Climate Change on the Salinity Situation of the Piyali River, Sundarbans, India
}

\author{
Sujana Dhar \\ Water Resources Policy \& Management, Water Resources Division, \\ The Energy \& Resources Institute, New Delhi, India \\ E-mail: sujana.dhar@teri.res.in \\ Received February 9, 2011; revised April 8, 2011; accepted June 3, 2011
}

\begin{abstract}
The Sundarbans, an UNESCO Heritage site has a large rural population which depends on natural resources for sustenance. The present paper deals with the management of the salt water intrusion of the Piyali River a tributary of the Matla River which empties into the Bay of Bengal. The study also delves into the population affected by the effects of the perennially saline river and their dependence on it for their livelihood. A look into the soil texture, seasonal variation in chloride content of soil along with $\mathrm{pH}$ and Electrical Conductivity (EC) levels of water sampled at different time and locations is analyzed in order to improve management options. With (EC) values of $17,000 \mathrm{mS}$ and $\mathrm{pH} 8.94$, sustaining the inhabitants in this area is quite challenging. Under the threat of climate change, increased levels of salinity arising from sea level rise and coastal flooding will pose a serious problem to the rural inhabitants of the Sundarbans. The predicted negative impacts of climate change are likely to bring new challenges in addition to magnifying existing problems, particularly in the Sundarbans community that already has limited capacity to adapt to these changes.
\end{abstract}

Keywords: Sundarbans, Salinity, Water Management, Piyali River, pH, EC, Sustainable Options

\section{Introduction}

India has rich estuarine and other brackish water resources along the east and west coasts formed by the Ganges, Mahanadi, Brahmputra, Godavari, Krishna, Cauvery, Narmada and Tapi rivers, and smaller coastal rivers along the west coast, mainly in Kerala, Kanrnataka and Goa. The total brackish water resources of India as estimated to be 1.44 million ha [1]. West Bengal is endowed with rich brackish water area, estimated to be 405,000 ha with Hoogly-Matla estuary accounting for $8,029 \mathrm{~km}^{2}$ and marshy area of Sunderbans to be $2,340 \mathrm{~km}^{2}$.

Geographically Sundarbans lies south-east of Kolkata in the 24-Paraganas District of West Bengal (India) and forms part of the Gangetic Delta, which borders on the Bay of Bengal. Altitude of the Sundarbans ranges from sea level to $10 \mathrm{~m}$ at the most. The whole Sundarbans area is intersected by an intricate network of Inter-connecting waterways, of which the larger channels are often a mile or more in width and run in a north-south direction. Tidal waves are a regular phenomenon and may be up to $7.5 \mathrm{~m}$ high. There are 54 islands in this region.

The land area measures about $9629 \mathrm{~km}^{2}$ of which
$4493 \mathrm{~km}^{2}$ is inhabitated by people and the rest is reserve forest. Major ecosystem type is tropical humid forest and mangroves. Socio-economic status is mainly dependent on the natural resources of Sunderban and agriculture. Slight degradation in aquaculture resources due to climate change may have detrimental effects on the socioeconomic status of the people living in this region.

\section{Study Area}

The selected study area is the Piyali River in Kultali block of South 24 Paraganas. Figures 1 and 2 illustrate the position of the Piyali River. Salinity is common problem in the South 24 Parganas, West Bengal (Figure 3). Sea water contains chlorides with other salts that can be detrimental to agricultural crops and which exceed drinking water standards. During the summer period when the saltwater intrusion becomes more severe due to extensive over pumping in the absence of the development of supplemental water supplies to the area. The livelihood of rural population mainly depends on the sustainable development and management of groundwater resources. Figure 4 shows the villages located in the 


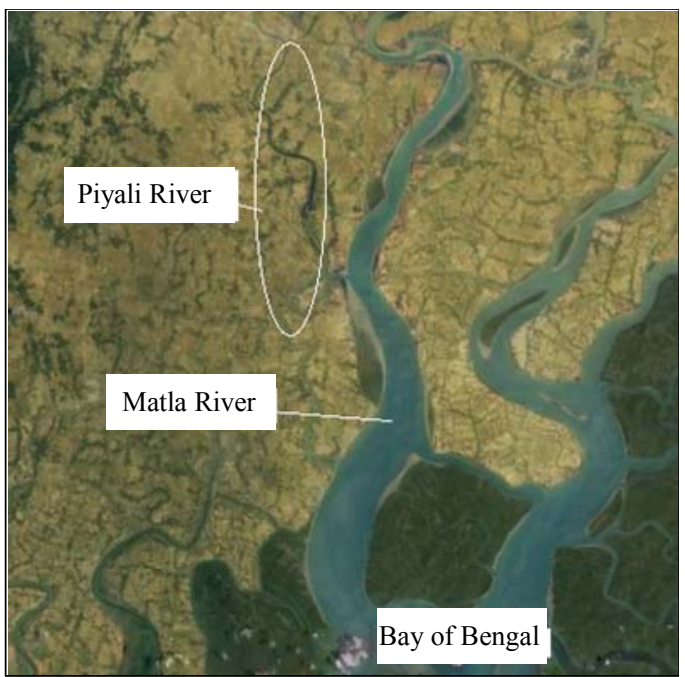

Figure 1. Satellite imagery of the Piyali River a tributary of the Matla River flowing towards the Bay of Bengal.

Kultali block.

The selected River basin is Piyali River basin (Figures 5 and 6) which is a perennially saline river. The otherwise sweet water river is affected by salt water intrusion from the Bay of Bengal through the Matla River. The Basin of the Piyali River, an estuarine river with regular tidal influx, during flash floods the entire catchments of the Piyali River overflows.

\section{Problem Identification}

At present, the main sources of traditional water supply are wells and bore wells and also from bore wells. But as salinity was fastly setting in the wells, around the coastal villages and towns of the peninsula, the need for pure drinking water has become the most priority issue. The existing tube wells, being very deep, have already become saline, and some way has to be found as quickly as possible to stop sea water seeping into these bottomless wells.

The saline water has affected the villages situated along the river. Absent of safe drinking water affects health of the villagers. Lack of potable water source leads to disease, adverse effects on health which in turn affects the country's GDP. Also lack of education, malnutrition further lowers the economic condition of the people of this region. The agriculture is being a main occupation; the socio economic condition is also poor. Brief description of the water problems/challenges in the locations of the Kultali block is covered in Table 1.

Solute transport is of concern in many hydro geological problems. Historically, first interest in solute transport in aquifers arose because of the problem of seawater intrusion. This was and still is a very practical and acute problem in coastal areas where one needs to keep production wells fresh. It is now realized that groundwater is not an inexhaustible natural resource. Groundwater is very vulnerable to contamination as a result of agricultural, industrial and urban activities. Society has to deal with both historical and ongoing unavoidable contamination of the environment.

Freshwater aquifers are bounded at their seaward margins by salt-water. Under natural conditions, the seaward

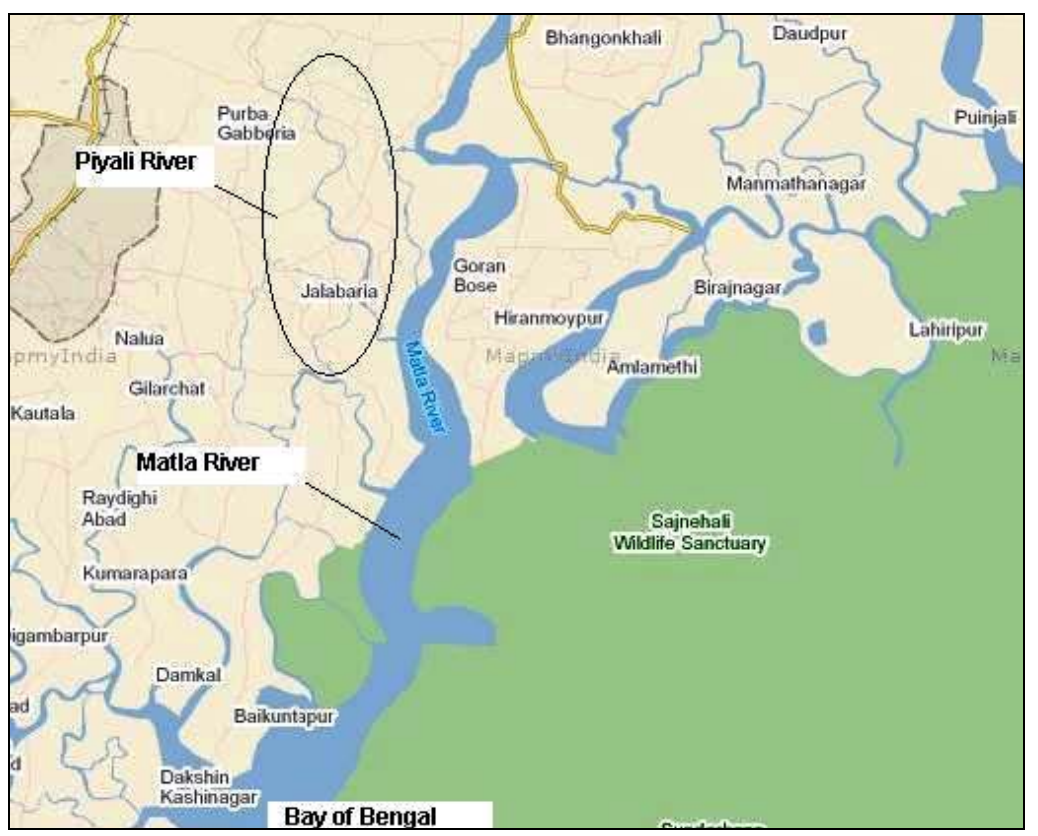

Figure 2. Map of the Piyali River a tributary of the Matla River flowing towards the Bay of Bengal. 


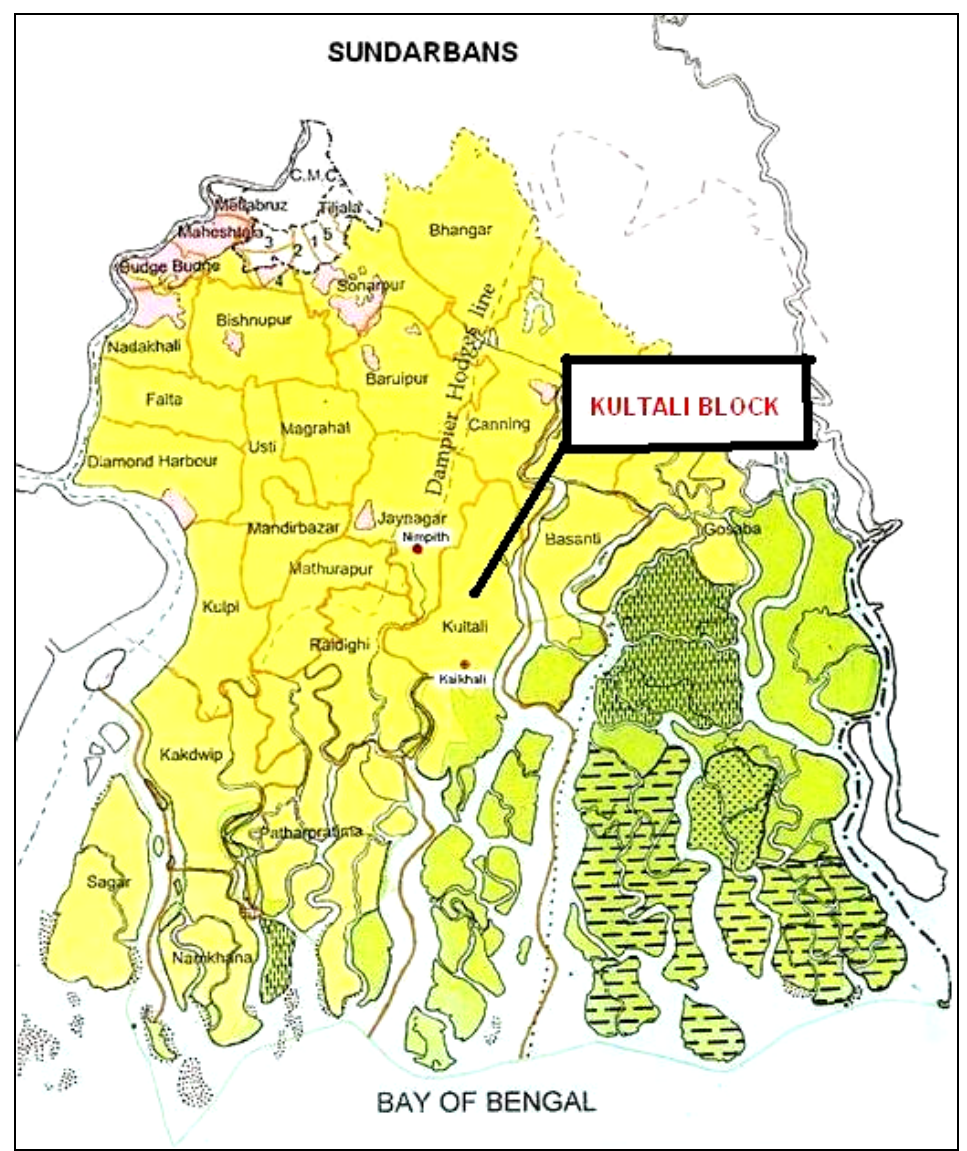

Figure 3. Location map of Kultali block in south 24 Parganas, west Bengal, India.

flow of freshwater prevents saltwater from encroaching coastal aquifers. Ground-water withdrawals, however, lower coastal water levels and can cause saltwater to be drawn landward and upward toward the points of withdrawal, a process called saltwater intrusion. Saltwater intrusion reduces ground-water storage and can lead to the abandonment of supply wells when concentrations of dissolved ions, such as chloride, in water withdrawn at the wells exceed drinking-water standards. The degree of saltwater intrusion along the coast varies widely, however, and is affected by the hydro geologic setting, history of ground-water development, and sources of saline water within a particular area.

The rate at which freshwater is being exploited from the aquifers greatly control the intrusion of saline water into the coastal aquifers. The phenomenon is common in the extensive coastal sedimentary deposits and delta of major rivers of the east coast of West Bengal. Seawater intrusion can be halted or prevented by maintenance of groundwater levels well above the sea level.

\section{Methodology}

The long term data included collection of climatological data (precipitation, temperature, evaporation, water level fluctuations, etc.) over the period of approximately three years, which will be correlated with other area full time climatological data stations. The focused surveys will include establishing topographic and water level elevation reference controls, geophysical surveys (electrical resistivity, electro-magnetics and possibly ground penetrating radar). The first stage of the project was initiated by collection of secondary data and literature survey coupled with a reconnaissance survey to identify the sampling points for collection of relevant primary data pertaining to study area. This was be followed by collection of socio-economic data with the help of questionnaires in order to conduct an extensive survey of the local residents and stakeholders of the Kultali block.

The next stage was to define the mechanisms of ground-water flow and movement of saltwater in the Piyali River aquifer and delineation of the paths and rates of ground-water flow and intrusion of saltwater into the Piyali River aquifer and simulate a variety of watermanagement scenarios to alleviate rates of saltwater contamination and to provide inhabitants with options to move away from over dependence on single source to multiple sources through conjunctive use of groundwater, 


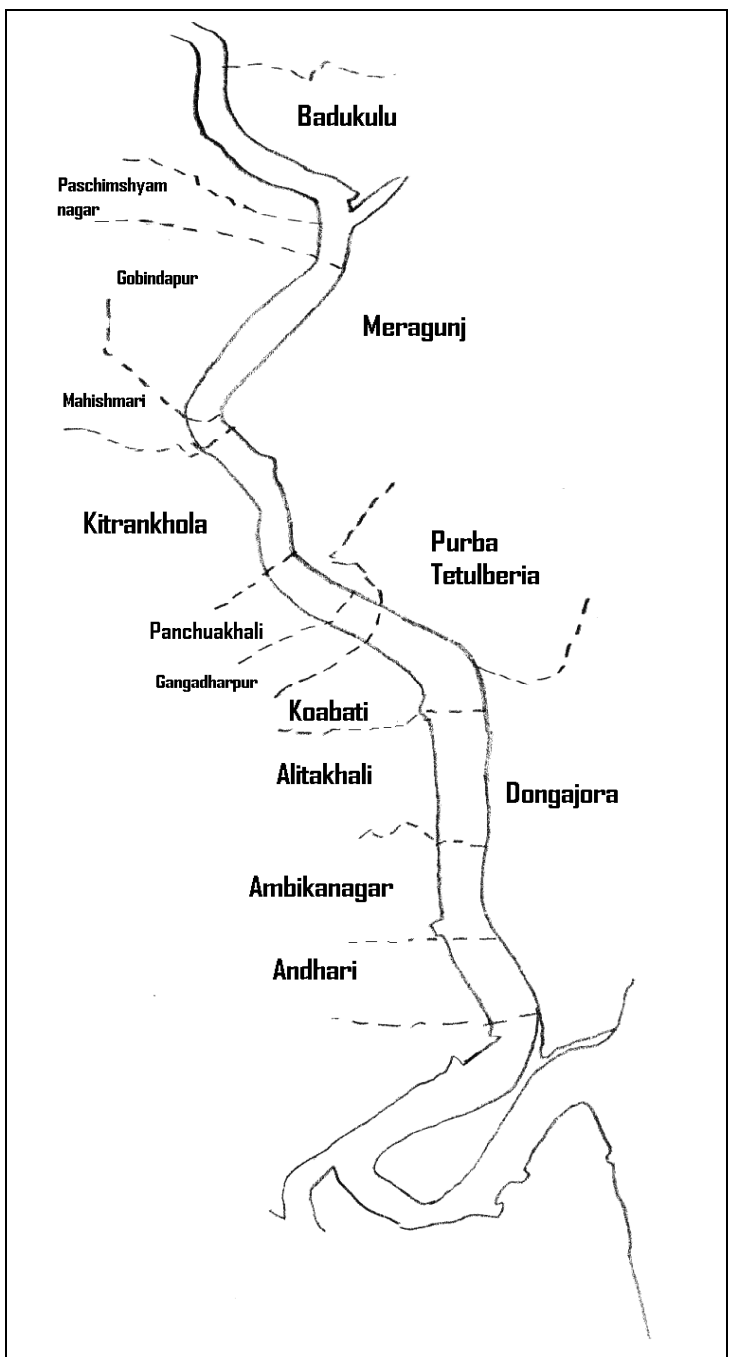

Figure 4. Village map of the Kultali block in the South 24 Parganas, West Bengal (scale 1:50,000).

surface water and rainwater harvesting.

Further, evaluation of present practices of pure water supply sources and further assessment of alternative sources of water supply from seepage ponds connected to the Piyali River aquifer based on issues of potability, reliability, sustainability, convenience and equity. Assessment of long-term ground-water levels and quality is equally important and the development and maintenance of a comprehensive groundwater data base in order to aid ensuring drinking water security through measures to improved/augmented existing drinking water sources and conjunctive use of groundwater, surface-water and rain water harvesting are also considered.

Table 2 illustrates the location of the sampling points and their respective coordinates within the Kultali block.

The instruments procured by the financial order of this project are provided in Table 3 which are been used for precision in salinity results.

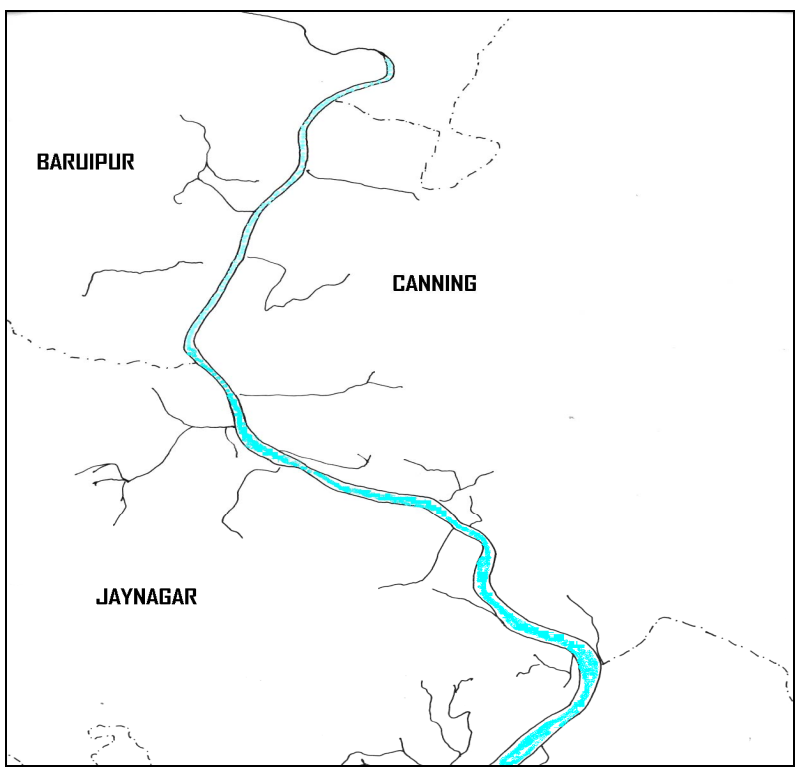

Figure 5. Upper Basin of the Piyali River spanning Baruipur, Jaynagar and Canning blocks of South 24 Parganas district of West Bengal state (scale 1:50,000).

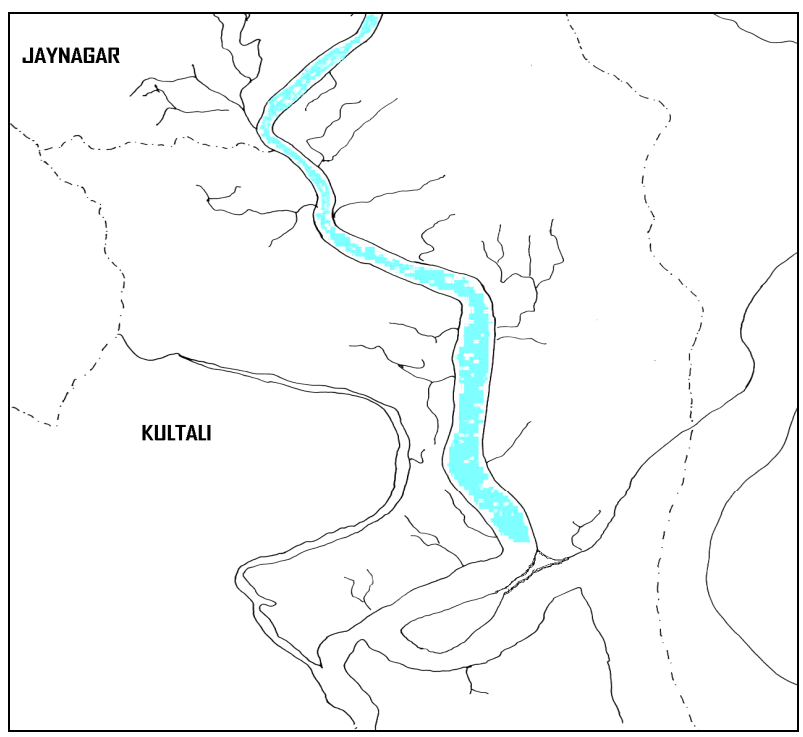

Figure 6. Lower Basin of the Piyali River through Jaynagar and Kultali blocks of South 24 Parganas district of West Bengal state (scale 1:50,000).

\section{Results \& Discussions}

\subsection{Water Quality Results of Samples Collected During Pre-monsoon'09}

Tables 4-6 illustrate the condition of the water quality samples that ere analysed during the monsoon season of the year 2009. Various ions such as N sodium, calcium, potassium, magnesium and other important parameters of $\mathrm{pH} \&$ conductivity were tested. 
Table 1. Locations within Kultali block.

\begin{tabular}{|c|c|c|}
\hline Name of village, Tehsil, District, State/UT and River basin & Population of village & Remarks \\
\hline Kaikhali, Kultali block, South 24 Parganas, West Bengal. Piyali River Basin & 5180 & \multirow{2}{*}{$\begin{array}{l}\text { BPL families with low } \\
\text { awareness levels }\end{array}$} \\
\hline Ambikanagar, Kultali block, South 24 Parganas, West Bengal. Piyali River Basin & 451 & \\
\hline Alitakhali, Kultali block, South 24 Parganas, West Bengal. Piyali River Basin & 2155 & \multirow{2}{*}{$\begin{array}{l}\text { Poor education and high } \\
\text { dependence on agriculture }\end{array}$} \\
\hline Koabati, Kultali block, South 24 Parganas, West Bengal. Piyali River Basin & 2175 & \\
\hline Gangadharpur, Kultali block, South 24 Parganas, West Bengal. Piyali River Basin & 825 & \multirow{3}{*}{$\begin{array}{l}\text { High dependence on } \\
\text { pissiculture and lack of } \\
\text { alternate job opportunities }\end{array}$} \\
\hline Panchua Khali, Kultali block, South 24 Parganas, West Bengal. Piyali River Basin & 654 & \\
\hline Kirtankhola, Kultali block, South 24 Parganas South, West Bengal. Piyali River Basin & 4083 & \\
\hline Meraganj, Kultali block, South 24 Parganas, West Bengal. Piyali River Basin & 6926 & $\begin{array}{l}\text { Lack of arable land holding } \\
\text { due to disintegration of joint } \\
\text { family system }\end{array}$ \\
\hline
\end{tabular}

Table 2. Location of sampling points and respective coordinates.

\begin{tabular}{cccc}
\hline Sr No & Location ID & Latitude N & Longitude E \\
\hline 1 & Sluice Gate & $22^{\circ} 08^{\prime} 7.9^{\prime \prime}$ & $88^{\circ} 35^{\prime} 53^{\prime \prime}$ \\
2 & Sluice + $1 \mathrm{~km}$ & $22^{\circ} 08^{\prime} 33.2^{\prime \prime}$ & $88^{\circ} 36^{\prime} 3.8^{\prime \prime}$ \\
3 & Alitakhali & $22^{\circ} 09^{\prime} 12.6^{\prime \prime}$ & $88^{\circ} 36^{\prime} 10.7^{\prime \prime}$ \\
4 & Sluice + 3 km & $22^{\circ} 09^{\prime} 28^{\prime \prime}$ & $88^{\circ} 36^{\prime} 11^{\prime \prime}$ \\
5 & New Bridge & $22^{\circ} 09^{\prime} 48^{\prime \prime}$ & $88^{\circ} 35^{\prime} 32^{\prime \prime}$ \\
6 & Jamtala BDO & $22^{\circ} 09^{\prime} 26^{\prime \prime}$ & $88^{\circ} 35^{\prime} 08^{\prime \prime}$ \\
7 & Panchuakhali & $22^{\circ} 10^{\prime} 3.4^{\prime \prime}$ & $88^{\circ} 34^{\prime} 59.6^{\prime \prime}$ \\
8 & Brick Kiln & $22^{\circ} 10^{\prime} 31^{\prime \prime}$ & $88^{\circ} 34^{\prime} 48.3^{\prime \prime}$ \\
9 & New Bridge + $4 \mathrm{~km}$ & $22^{\circ} 10^{\prime} 26^{\prime \prime}$ & $88^{\circ} 34^{\prime} 50^{\prime \prime}$ \\
10 & Maheshvari & $22^{\circ} 23^{\prime} 11.9^{\prime \prime}$ & $88^{\circ} 49^{\prime} 56.2^{\prime \prime}$ \\
\hline
\end{tabular}

Table 3. List of instruments.

\begin{tabular}{ccc}
\hline Sr No & Name of instrument & Manufacturer \\
\hline 1 & Orpheuse Mini GW Logger & OTT, Germany \\
2 & e + MCT Soil Probe & Eijelkamp, Netherlands \\
3 & Discrete Interval Water Sampler & Soilinst, Canada \\
4 & TLC Water Meter & Soilinst, Canada \\
5 & Rain Data Logger & Spectrum, USA \\
\hline
\end{tabular}

Tables $\mathbf{7}$ and $\mathbf{8}$ describe the standards of water quality based on the ion analysis.

\subsection{Water Quality Guidelines}

The values for permissible limits considered fit for pota-
Table 4. Variation of ions during Monsoon'09 for both surface \& ground water.

\begin{tabular}{ccccccc}
\hline Sample & $\mathrm{pH}$ & $\begin{array}{c}\mathrm{EC} \\
(\mathrm{dS} / \mathrm{m})\end{array}$ & $\begin{array}{c}\mathrm{Na}^{+} \\
(\mathrm{meq} / \mathrm{l})\end{array}$ & $\begin{array}{c}\mathrm{K}^{+} \\
(\mathrm{meq} / \mathrm{l})\end{array}$ & $\begin{array}{c}\mathrm{Ca}^{++} \\
(\mathrm{meq} / \mathrm{l})\end{array}$ & $\begin{array}{c}\mathrm{Mg}^{++} \\
(\mathrm{meq} / \mathrm{l})\end{array}$ \\
\hline $\mathrm{SW}$ & & & & & & \\
1 & 8.10 & $\mathbf{1 0 . 5 3 ( H S )}$ & 105.00 & 1.19 & 8.60 & 11.90 \\
2 & 7.90 & $\mathbf{1 2 . 3 3 ( H S )}$ & 93.80 & 3.11 & 14.70 & 22.10 \\
3 & 7.90 & $\mathbf{1 2 . 2 4 ( H S )}$ & 91.30 & 3.65 & 11.00 & 22.00 \\
4 & 7.90 & $\mathbf{9 . 7 2 ( M S )}$ & 92.50 & 1.61 & 9.70 & 12.30 \\
5 & 8.00 & $\mathbf{6 . 3 9 ( M S )}$ & 62.00 & 1.13 & 8.20 & 10.00 \\
6 & 8.10 & $\mathbf{1 1 . 7 ( H S )}$ & 97.50 & 3.03 & 7.60 & 12.80 \\
$\mathrm{GW}$ & & & & & & \\
1 & 7.70 & $\mathbf{6 . 9 3 ( M S )}$ & 60.00 & 1.38 & 8.00 & 12.80 \\
2 & 7.90 & $\mathbf{5 . 7 6 ( M S )}$ & 67.00 & 1.62 & 8.30 & 16.70 \\
3 & 7.90 & $\mathbf{5 . 9 4 ( M S )}$ & 95.00 & 1.19 & 9.40 & 15.00 \\
\hline
\end{tabular}

Location: Kultali (South 24 Parganas), W.B.

ble water are given in Table $\mathbf{9}$. Table $\mathbf{1 0}$ states the ranking of conductivity and other parameters for water quality analysis. The folmulae employed during the analysis are given in Table 11.

$$
\begin{gathered}
\% \mathrm{Na}=\left(\mathrm{Na}^{+}+\mathrm{K}^{+}\right) /\left(\mathrm{Na}^{+}+\mathrm{K}^{+}+\mathrm{Ca}^{++}+\mathrm{Mg}^{++}\right) * 100 \\
\mathrm{SAR}=\mathrm{Na}^{+} / \sqrt{ }\left(\mathrm{Ca}^{++}+\mathrm{Mg}^{++}\right) / 2
\end{gathered}
$$

\subsection{Seasonal Variations of Chemical Parameters in Groundwater for the Year 2009}

The composition of the groundwater that was collected and analysis during the entire span of year 2009 has been presented in 2009. Conductivity, sodium ions, calcium ions and magnesium ions along with other parameters 
Table 5. Variation of ions during Monsoon'09 for both surface \& ground water.

\begin{tabular}{cccccc}
\hline Sample & $\mathrm{Na}^{+}+\mathrm{K}^{+}(\mathrm{meq} / \mathrm{l})$ & $\mathrm{Ca}^{++}+\mathrm{Mg}^{++}(\mathrm{meq} / \mathrm{l})$ & $\sqrt{ }\left(\mathrm{Ca}^{++}+\mathrm{Mg}^{++}\right) / 2$ & $\mathrm{Ca}^{++} / \mathrm{Mg}^{++}$ & $\mathrm{Na}^{+}+\mathrm{K}^{+}+\mathrm{Ca}^{++}+\mathrm{Mg}^{++}(\mathrm{meq} / \mathrm{l})$ \\
\hline $\mathrm{SW}$ & & & & & \\
1 & 106.19 & 20.50 & 3.20 & 0.72 & 126.69 \\
2 & 96.91 & 36.80 & 4.29 & 0.67 & 133.71 \\
3 & 94.95 & 33.00 & 4.06 & 0.50 & 127.95 \\
4 & 94.11 & 22.00 & 3.31 & 0.79 & 116.11 \\
5 & 63.13 & 18.20 & 3.01 & 0.82 & 81.33 \\
6 & 100.53 & 20.40 & 3.19 & 0.59 & 120.93 \\
$\mathrm{GW}$ & & & & & \\
1 & 61.38 & 20.80 & 3.22 & 0.63 & 82.18 \\
2 & 68.62 & 25.00 & 3.54 & 0.50 & 93.62 \\
3 & 96.19 & 24.40 & 3.49 & 0.63 & 120.59 \\
\hline
\end{tabular}

Table 6. Variation of ions during Monsoon'09 for both surface \& ground water.

\begin{tabular}{|c|c|c|c|c|}
\hline Sample & $\mathrm{SO}_{4}^{-} \quad(\mathrm{meq} / \mathrm{l})$ & $\mathrm{Cl}^{-}(\mathrm{meq} / 1)$ & $\% \mathrm{Na}$ & SAR \\
\hline \multicolumn{5}{|l|}{ SW } \\
\hline 1 & 20.40 & 2.20 & 83.82 & 32.81 (VHSAR) \\
\hline 2 & 36.70 & 6.20 & 72.48 & 21.86 (HSAR) \\
\hline 3 & 31.50 & 4.60 & 74.21 & 22.49 (HSAR) \\
\hline 4 & 21.40 & 2.10 & 81.05 & 27.95 (VHSAR) \\
\hline 5 & 18.20 & 4.70 & 77.62 & 20.60 (HSAR) \\
\hline 6 & 20.30 & 7.70 & 83.13 & 30.56 (VHSAR) \\
\hline \multicolumn{5}{|l|}{ GW } \\
\hline 1 & 20.70 & 2.20 & 74.69 & 18.63 (HSAR) \\
\hline 2 & 24.40 & 2.30 & 73.30 & 18.93 (HSAR) \\
\hline 3 & 23.80 & 2.10 & 79.77 & 27.22 (VHSAR) \\
\hline
\end{tabular}

Table 7. Water quality standards.

\begin{tabular}{cl}
\hline $\mathrm{Ca} / \mathrm{Mg}$ & $\begin{array}{l}<0.25 \text { indicates allowing more } \mathrm{Na}^{+} \text {adsorption by soils and clay minerals and thus soil sodicity would } \\
\text { increase if such water is used for irrigation }\end{array}$ \\
$\mathrm{MNa}$ & $>60$ indicates beyond permissible limit \\
$\mathrm{MS}$ & Moderately Saline \\
$\mathrm{HS}$ & Highly Saline \\
MSAR & Medium SAR \\
HSAR & High SAR \\
VHSAR & Very High SAR \\
\hline
\end{tabular}

Table 8. Water quality standards.

\begin{tabular}{cl}
\hline & \multicolumn{1}{c}{ Comments on water Quality } \\
\hline SW & $\begin{array}{l}\text { Medium to High Salinity; Medium SAR; \%Na more or less beyond permissible limit; pH within } \\
\text { permissible limit }\end{array}$ \\
GW & High Salinity; High SAR; \%Na beyond permissible limit; pH within permissible limit \\
\hline
\end{tabular}

$\mathrm{Cl}^{-}$remains within permissible limit in both SW \& GW. 
Table 9. Table of standards.

\begin{tabular}{ccc}
\hline & ICAR (Irri) & IS 10500(Drink) \\
\hline $\mathrm{pH}$ & 6.5 to 8.5 & 6.5 to 8.5 \\
$\% \mathrm{Na}$ & 60 & \\
$\mathrm{SAR}$ & 26 & \\
$\mathrm{Cl}^{-}$ & 600 & 1000 \\
$\mathrm{Ca}^{2+}$ & & 200 \\
$\mathrm{Mg}^{2+}$ & & 100 \\
\hline
\end{tabular}

Table 10. Table of standards.

\begin{tabular}{cc}
\hline EC(dS/m) & \\
$<3$ & Low Salinity \\
3 to 9 & Medium Salinity \\
$>10$ & High salinity \\
\hline SAR & Low SAR \\
$<10$ & Medium SAR \\
10 to 18 & High SAR \\
18 to 26 & Very High SAR \\
$>26$ & \\
\hline $\mathrm{RSC}$ & Low \\
$<1.5$ & Medium \\
1.5 to 3 & High \\
3 to 6 & Vey High \\
$>6$ & \\
\hline $\mathrm{Ca}^{2+} / \mathrm{Mg}^{2+}$ & Alarming \\
\hline$<0.25$ &
\end{tabular}

are accessible in Tables $\mathbf{1 1}$ and $\mathbf{1 2 .}$

\section{Conclusions \& Recommendations}

Saltwater intrusion may occur due to anthropogenic activities and natural events such as climate change and sea level rise. Saltwater intrusion is major barrier to utilizetion of groundwater for domestic and agricultural purposes. Groundwater is used by approximately $50 \%$ world population so saltwater intrusion should be prevented or at least controlled. Artificial recharge possibilities must be examined in this area to refill the over pumped portions of the aquifer so as to reduce the effect of contamination.

In reality it is very difficult and very costly to re-establish the previous natural conditions since back-washing of the aquifer from the salts is not only a time-dependent process but generally is assumed to be irreversible. Public
Table 11. Variation in parameters for the year 2009.

\begin{tabular}{lcccccc}
\hline & $\mathrm{pH}$ & $\begin{array}{c}\mathrm{EC} \\
(\mathrm{dS} / \mathrm{m})\end{array}$ & $\begin{array}{c}\mathrm{Na}^{+} \\
(\mathrm{meq} / \mathrm{l})\end{array}$ & $\begin{array}{c}\mathrm{K}^{+} \\
(\mathrm{meq} / \mathrm{l})\end{array}$ & $\begin{array}{c}\mathrm{Ca}^{2+} \\
(\mathrm{meq} / \mathrm{l})\end{array}$ & $\begin{array}{c}\mathrm{Mg}^{2+} \\
(\mathrm{meq} / \mathrm{l})\end{array}$ \\
\hline $\begin{array}{c}\text { Pre Monsoon } \\
2009\end{array}$ & 7.3 & 11.205 & 118.75 & 4.31 & 3.25 & 0.85 \\
$\begin{array}{c}\text { Monsoon 2009 } \\
\begin{array}{c}\text { Post-Monsoon } \\
\text { 2009 }\end{array}\end{array}$ & 7.83 & 6.21 & 74 & 1.4 & 8.57 & 14.83 \\
\hline
\end{tabular}

Table 12. Variation in ions for the year 2009.

\begin{tabular}{ccccc}
\hline & $\mathrm{SO}_{4}^{-}(\mathrm{meq} / \mathrm{l})$ & $\mathrm{Cl}^{-}(\mathrm{meq} / \mathrm{l})$ & $\% \mathrm{Na}$ & $\mathrm{SAR}$ \\
\hline Pre Monsoon 2009 & 3.9 & 26.05 & 96.78 & 83.06 \\
Monsoon 2009 & 22.97 & 2.2 & 75.92 & 24.71 \\
Post-Monsoon 2009 & 40.75 & 3.06 & 23.42 & 2.69 \\
\hline
\end{tabular}

should be awaked about water resources to raise the efficiency of overall water use to the maximum limit. The efficient irrigation systems should be used or be madder available to the farmers. Salt tolerant and drought resistant crop varieties be developed and made available to the local farmers to reduce pressure on the freshwater sources in the study area.

The available techniques for managing groundwater levels in irrigation areas are well established. They include:

- Improved on-farm water use efficiency to minimise groundwater replenishment from deep drainage;

- Improved irrigation water storage and conveyance efficiencies to prevent leakage from the irrigation infrastructure;

- Groundwater pumping wells to enhanced discharge;

- Groundwater gravity drainage systems, including deep open surface drains and subsurface drains; and

- Tree planting to lower shallow water tables and reduce deep drainage.

\subsection{Improving Water Use Efficiency}

Improved water use efficiency is beneficial because it reduces the rate of groundwater replenishment and avoids the subsequent cost of removing surplus groundwater storage by constructed drainage systems. On the other hand, water use efficiency improvements are unlikely to mitigate completely shallow water tables in the Piyali River, because:

- The irrigation scheme is a flow-through system that diverts large volumes of river water through many kilometres of unlined supply channels and drains;

- The impracticality and large cost of lining the conveyance system to eliminate leakage is considered to 
be prohibitive;

- It is difficult and undesirable to achieve one-hundred percent on-farm water application efficiency because that would prevent deep drainage and salt leaching beyond the soil root zone; and

- It is evident from recent groundwater monitoring that wet season rainfall has become an important control on groundwater level that is unrelated to irrigation water use efficiency.

The option to leak-proof sections of supply channels and drains using impermeable liners has been considered previously (SKM, 1998a). This option is not investigated in the present study because important areas of leakage from supply channels have not been determined - either now or in the past.

\section{- Pumping Wells}

- Total pumping is balanced against excess groundwater recharge from both irrigation and rainfall; and

- A suitable number of pumping locations can be established where large pumping rates are possible and the pumping does not induce significant additional recharge from surface water sources.'

Groundwater pumping wells are expected to be ineffective in areas where the palaeochannel is absent and lateral groundwater transmission is poor. In this situation, low bore yields limit the amount of groundwater that can be pumped and restrict the area of water table drawdown to a small radius around the bores. If present, local occurrences of more conductive sediments (e.g., discontinuous "lenses" and "stringers" of gravel and sand) may provide a suitable target for a local groundwater pumping strategy.

Groundwater pumps are not recommended where there is a strong groundwater connection between the aquifer and the Piyali River and pumping would drawdown the water table below the lake level. Pumping bores that are too close to the lake are likely to draw large amounts of lake water through the pumping scheme and be ineffective at controlling both the water table and the aquifer water balance.

\section{- Drains}

When sediment permeability and surface relief are adequate, natural subsurface drainage may be enough to prevent shallow water tables from developing under irrigation; however, these conditions are rare in areas where saline soils occur. Various types of constructed groundwater drainage systems are used successfully throughout the world, including open ditches that intercept the water table, and subsurface tile drains and perforated plastic pipes. The optimal depth and spacing of drains depends upon the soil characteristics (e.g., layering and permeability) and the local economic considerations.

Open surface drains are now thought to be discharging considerable volumes of groundwater - though they were not designed for this purpose. Subsurface drainage systems have not been tried but they may provide a viable option for controlling the water table in areas where pumping wells are impracticable and the existing surface drains are inadequate.

\section{- Trees}

Tree plantations can dramatically lower the water table through decreasing local groundwater replenishment and increasing transpiration. In this particular case, the water table drawdown was large but restricted to the immediate area of the plantation. In areas where the aquifer has small transmissivity, tree plantations may be effective at lowering the local water table but this advantage may not be sustainable in the long-term due to salt accumulation in the root zone.

In areas underlain by palaeochannel, irrigated tree plantations are unlikely to have a significant effect on the local water table but may help to reduce subsurface drainage from the palaeochannel system if the leaching fraction beneath the trees is less than for other crop types. An additional advantage may be gained if the trees can derive a portion of their water requirement directly from the water table [2]. The results from numerous groundwater pumping tests [3] provide clear evidence that small water table drawdowns would occur beneath trees that are planted over the palaeochannel system.

Commercially grown dryland (unirrigated) trees that obtain a significant proportion of their water requirement from the watertable would provide the best benefits with respect to water and salt balance management.

Importantly, trees should not be considered as straightforward substitutes for groundwater pumping wells. While mechanical groundwater pumps remove both water and solutes from the aquifer, trees remove only water and concentrate the solutes in the subsurface. If trees are used to manage the aquifer water balance then the subsurface salt balance and sustainability of tree growth also must be considered. To prevent harmful accumulation of salt in the root zone of irrigated crops, total irrigation and rainfall must exceed total evapotranspiration, and that excess must pass through the root zone in a minimum amount - called the "leaching fraction". This fraction can be minimised through careful management; however, subsurface drainage is an unavoidable element of sustainable irrigated agriculture.

\subsection{Salinity Risk Areas}

The risk of secondary salinity can be assessed based on the historic rate of groundwater rise, current groundwater conditions and predicted water table responses to future groundwater replenishment scenarios. Three risk classes 
defined are:

Groundwater Management Options to Control Rising Groundwater Level and Salinity in the Piyali River

- Low salinity risk - greater than 4 metres depth to the water table;

- Moderate salinity risk - between 2 and 4 metres depth to the water table; and

- High potential salinity risk - less than 2 metres depth to the water table.

The above high risk class is a measure of potential salinity risk only because depth to water table, alone, does not determine whether salinity will develop. Groundwater quality and the local direction of groundwater drainage also are important factors. If the water table is less than two metres below ground surface (high potential risk) but there is net replenishment of groundwater and net downward drainage, then subsurface salt accumulation and salinity formation are unlikely. In this case, the potential for water logging may be more of a concern.

On the other hand, if subsurface drainage is slow and there is net discharge of groundwater from the water table, then salinity formation is likely. Predicting whether salinity will develop locally in areas of shallow water table using a valley scale modelling tool is difficult. Modelling at this large-scale is important for understanding the aquifer water balance and valley-scale water table behaviour but it cannot incorporate the local hydrogeological conditions and soil characteristics (e.g., local layering) that control subsurface drainage at the local-scale. The approach in this study was to classify areas of shallow water table as having a high potential salinity risk and recommend targeted monitoring for signs of emergent salinity.

Areas with a high potential salinity risk $(<2$ metres depth to water table) and evidence of emergent salinity require immediate management to lower the water table and leach the accumulated salt from the soil profile. Areas with low to moderate salinity risk $(>2$ metres depth to water table) should be monitored to ensure that the water table remains at a safe distance below ground surface and there is no emergent sign of salinity formation.

\section{Acknowledgements}

Authors sincerely acknowledge the kind assistance, rendered in the form of data and all kinds of secondary information by the officials and personnel of the Indian Meteorological Department, Central Water Commission and All India Soil and Land Use Survey, Survey of India, National Thematic Mapping Organization and National Bureau of Soil Survey and Land Use Planning and Irrigation and Waterways Directorate.

Financial assistance provided by DST Fast Track Young Scientist Scheme, DST, Ministry of Science \& Technology is gratefully acknowledged. Appreciation also goes to all faculty and staff of Water Quality Laboratory at the School of Water Resources, Jadavpur University, Kolkata. Gratitude also goes to the anonymous reviewer whose recommendations greatly added value to the paper and its findings.

\section{References}

[1] SKM, "Ord River Irrigation Area Stage 1, Control of Rising Water Level," Report to Water Corporation Western Australia, Sinclair Knight Merz, November 1998 (unpublished)

[2] J. E. Ayars, E. W. Christen, R. W. O. Soppe, J. W. Hornbuckle and R. A. Schoneman, "In-Situ Crop Water Use from Shallow Ground Water to Reduce Drainage and Save Irrigation Water," Proceedings of the International Salinity Forum, Managing Saline Soils and Water, Riverside, 25-27April 2005, pp. 25-28.

[3] A. J. Smith, D. W Pollock, R. B. Salama and D. Palmer, "Ivanhoe Plain Aquifer Pumping Trial July 2003 - April 2005: Stage 1 Ord River Irrigation Area, Kununurra, Western Australia," CSIRO Land and Water Technical Report 24/05, 2005. 